\title{
Introduction: Criminality and carcerality across boundaries
}

\author{
J. Turner \\ Department of Criminology, University of Leicester, Leicester, UK \\ Correspondence to: J. Turner (jt264@leicester.ac.uk)
}

Received: 22 October 2014 - Accepted: 12 December 2014 - Published: 22 December 2014

For the last 5 years, most of the conference papers I have presented or articles I have written have begun with the usual obligatory introduction to the "newly emerging" subdiscipline of carceral geography. That is, of course, research "specifically alighting on the spaces set aside for 'securing' - detaining, locking up/away - problematic populations of one kind or another" (Philo, 2012:4). However, to paraphrase a colleague participating in one of three sessions entitled "Mapping Carceral Geography" at the 2014 Royal Geographical Society of the Institute of British Geographers, "we do not need to keep saying this anymore; we have definitely emerged". This got me to thinking about the politics of emergent or indeed "recently emerged" areas of a discipline and their propensity to continue their momentum to become both prolific in their own right and sustain academic longevity. In short, what does a newly emerged discipline do next?

In part, this special issue is both manifesto and a conscious implementation of it. In asking which way to turn next with the sub-discipline, this issue draws upon work carried out in its "emergence" surrounding the complex and often blurred relationship between prison and society, exploring carcerality across boundaries (Baer and Ravneberg, 2008; Gilmore, 2007; Loyd et al., 2009; Pallot, 2005; Vergara, 1995; Wacquant, 2000, 2001a, b, 2009). However, in doing so, this issue also begins to pave the way for future intentions.

Much geographical literature has related specifically to the reification and permeabilities of boundaries (Conlon and Gill, 2013; Moran et al., 2011, 2012; Turner 2013a) - and the crucial role that prison has played in the economic composition of society (Bonds, 2013; Venn, 2009). Peck, for example, argues that in a neoliberal economy the prison system has become central, as opposed to invisible and distant (2003:223), insofar as it has become a site of privatisation and commodification of services more traditionally associated with a state welfare.
In general, there is increasing "leakage" and increasingly complex bundle of cultural, economic and political relations that undermines any simple distinction between the "carceral inside" and the "public outside". Carceral geography has expanded its repertoire to meet this demand. Detention centres in particular have become a means of debating and interrogating the everyday politics, as well as the legal framing, of an extended state sovereignty and an accompanying erasure of human rights (Gill, 2009; Martin and Mitchelson, 2009). Other scholarship has explored the impact of "outsider" identity constructions upon regimes of imprisonment (Moran et al., 2009; Turner, 2012). Work by Moran (2013) has examined the visiting room as a liminal space between inside and outside, and my own research has considered prisoners' attachments to "home" across the prison boundary (Turner, 2013b).

In what follows, this special issue promotes a trajectory for carceral geography to broaden the horizons of its practical application, having successfully carved a niche for itself as a stand-alone strand of human geography. It further explores how carcerality manifests itself across boundaries - that is, not only the boundary of the prison itself but also regional and national boundaries - bringing global issues to carceral space, and vice versa.

This special issue brings together seven papers, which provide a range of empirical examples that highlight the social, political, economic and cultural manifestations of the complexity of the relationship between carceral spaces and the world around them. The special issue is aimed at generating reflection and exchange on how themes typically considered carceral can inform imaginations of, as well as policing and governmental projects centred upon, nominally more "open" civic or public realms. Likewise, it is important to understand the ways in which urban (or rural) imaginations of civic or 
public space as well as spaces of economic exchange inflect the evolution of carceral policies and practices.

Taken together, the papers in this special issue highlight implications for a number of fields, including, amongst others, the governance and economy of carceral spaces, environmental politics, global mobility, bodily treatment of individuals and youth justice. Although the contributions are drawn from a range of geographical locations and at different scales, the theme of the synergies between carceral and everyday space runs throughout.

Matthew Mitchelson's paper opens the collection through a discussion of for-profit imprisonment in the United States, identifying bedspace as a concept upon which the publicversus-private debate can find some common ground. Theorising bedspace as something commodified and bureaucratised, yet also "messy" and lived in its experience, Mitchelson demonstrates the capital flows that build and move, often beyond prison boundaries. Similarly, Deirdre Conlon and Nancy Hiemstra's paper also acknowledges the significance of the privatisation of large proportions of the detention estate in countries, such as the UK and the US. This paper examines the social and political practices and process of contracts for migrant detention facilities in the northeast of the United States, exploring their impact upon what they term the "micro-economies" of migrant detention. In doing so, Conlon and Hiemstra also expose the economic links across carceral boundaries that manifest themselves at the everyday and minute scale. In the third paper, Dominique Moran and Yvonne Jewkes introduce the notion of the "green" prison, to highlight the implication of environmental sustainability debates upon carceral policies and practices. This paper explores how ideas surrounding "organizational sustainable development" are echoed in a green prison discourse, which serves to distract from rising costs of mass incarceration in the United States. In concluding, Moran and Jewkes call for a complementary interpretation of the nurturing environment of the green prison - a positive, albeit context-dependent, possibility. These opening papers identify clear situations where wider institutional politics have a cross-boundary impact upon carceral spaces themselves, and in turn serve to re-constitute our understanding of any such boundary itself. The remaining papers attend to the boundary traffic that travels in the opposite direction, focusing upon how concepts and processes identified in carceral spaces have a pertinent relevance to the world around them.

Brett Story's paper explores the debilitative psychological damage caused by long-term solitary confinement of prisoners. Drawing upon theorisations of individuation, this paper posits that experiences of solitary confinement can share similarities with any or all situations and circumstances in everyday life. In using the material experiences of spatially isolated prisoners, the paper challenges the very ontology of the individual subject in modern life. In a similar vein, the fifth paper also illustrates how disciplinary spatial regimes can be applicable to situations physically "outside" of the carceral setting. Martijn Felder, Claudio Minca and Chin Ee Ong exemplify the management of "problematic" refugees at Amsterdam's Lloyd Hotel as a "quasi-carceral regime". In doing so, this paper demonstrates how bio-, macro- and micro-politics had serious implications for refugees in the prelude to the Second World War. Following this, Elizabeth Brown's paper traces how carceral apparatus has permeated into neighbourhoods and communities outside of prison. Exemplifying here mechanisms particularly relating to preventing juvenile delinquency, which contribute to processes of "sorting, placing and punishing", Brown calls for a more expansive understanding of the carceral state. The final paper may serve to answer that call by alluding to a transnational and literally fluid conceptualisation of carceral regimes via consideration of both onshore and offshore detention sites. Alison Mountz and Jenna Loyd's paper completes the issue by complicating notions of remoteness in carceral spaces, drawing upon the creation of "buffer zones" as an attempt to reinforce the distance between inside and outside in a world shaped by the prolific expansion of detention.

Collectively, these papers do much to expand the repertoire of carceral geography to transform its capacity as a merely burgeoning sub-field to one that is firmly rooted to human geography more broadly. First, by adding this collection to existing empirical and theoretical work on-going in carceral geography, these papers serve to strengthen this sub-field as a stand-alone segment of geography. Second, and crucially, in being critical of how carceral spaces can inform imaginations of public realms, the paradigms of carceral geography literature now make themselves applicable to research being undertaken around the discipline, further solidifying the work that carceral geography does to advance the discipline of geography as a whole. Thinking "carcerally" can help us to re-think the fundamental tenets of geography. Core geographical concerns relating to territory, mobility and temporality can all be thought of anew through the framework provided by carceral geography. Carcerality provides a condition (or set of conditions) that alter how we might usefully engage with such terms. How, for example, do territories of governance and control function within the set boundaries of the prison and across those boundaries? As alluded to throughout this introduction, how does territory and territorial power expand through the regulation of subjects held within, and released from, the prison sphere? Moreover, how might the power relations implicit in, and contested within, carceral regimes alter our understandings of mobility (and, crucially, immobilty) and how incarcerated individuals are moved, or able to move, in detention complexes, holding centres, prisons and other carceral spaces? Time, notably, might be usefully re-interrogated through a carceral lens as notions of cycles, rhythms and sentences come to the fore. In short, carceral geography, it could be argued, may complicate how we traditionally understand human engagements with(in), and across, space. 
Going beyond this issue, this collection of papers present some interesting dilemmas. First, we may consider whether drawing a line between inside and outside is now necessary. How do regimes of governance cross carceral borders in ways such that carceral spaces become ones of global imaginations? And, at the other end of scale, how may we consider further the imagination of carceral space upon everyday imaginations - both within that space and outside of it? With such strengths going forward, and such crucial interventions to be made, accordingly, I would encourage my colleagues in carceral geography to replace their "emergent" terminology with something altogether more fitting: well-established, evolutionary and/or here to stay.

Acknowledgements. I would like to extend my thanks to the many reviewers involved in the production of this special issue, who provided insightful guidance to both the authors and myself. I would also like to offer particular thanks to Jessica Heesen for her involvement in the early conceptualisation of the issue.

Edited by: B. Korf

Reviewed by: one anonymous referee

\section{References}

Baer, L. D. and Ravneberg, B.: The outside and inside in Norwegian and English prisons, Geogr. Ann. B., 2, 205-216, 2008.

Bonds, A.: Economic development, racialization, and privilege: "Yes in my backyard" prison politics and the reinvention of Madras, Oregon, Ann. Assoc, Am. Geogr., 101, 1389-1405, 2013.

Conlon, D. and Gill, N.: Gagging orders: asylum seekers and paradoxes of freedom and protest in liberal society, Citizenship Studies, 17, 241-259, 2013.

Gill, N.: Governmental mobility: The power effects of the movement of detained asylum seekers around Britain's detention estate, Polit. Geogr., 28, 186-196, 2009.

Gilmore, R. W.: Golden Gulag: Prisons, Surpluses, Crisis, and Opposition in Globalizing California, University of California Press, London, 2007.

Loyd, J., Burridge, A., and Mitchelson, M.: Thinking (and moving) beyond walls and cages: bridging immigrant justice and antiprison organizing in the United States, Social Justice, 36, 85103, 2009
Martin, L. L. and Mitchelson, M. L.: Geographies of detention and imprisonment: interrogating spatial practices of confinement, discipline, law, and state power, Geography Compass, 3, 459477, 2009.

Moran, D.: Between outside and inside? Prison visiting rooms as liminal carceral spaces, Geoj., 78, 339-351, 2013.

Moran, D., Pallot, J., and Piacentini, L.: Lipstick, lace and longing: constructions of femininity within a Russian prison, Environ. Plann. D., 27, 700-720, 2009.

Moran, D., Pallot, J., and Piacentini, L.: The geography of crime and punishment in the Russian Federation, Eurasian Geog. Econ., 52, 79-104, 2011.

Moran, D., Piacentini, L., and Pallot, J.: Disciplined mobility and carceral geography: prisoner transport in Russia, T. I. Brit. Geogr., 37, 446-460, 2012.

Pallot, J.: Russia's penal peripheries: space, place and penalty in soviet and post-Soviet Russia, T. I. Brit. Geogr., 30, 98-112, 2005.

Peck, J.: Geography and public policy: mapping the penal state, Prog. Hum. Geog., 27, 222-232, 2003.

Philo, C.: Security of geography/geography of security, T. I. Brit. Geogr., 37, 1-7, 2012.

Turner, J.: Criminals with "community spirit": practising citizenship in the hidden world of the prison, Space and Polity, 16, 321$334,2012$.

Turner, J.: Disciplinary engagements with prisons, prisoners and the penal system, Geography Compass, 7, 35-45, 2013a.

Turner, J.: Re-"homing" the ex-offender: constructing a "prisoner dyspora", Area, 45, 485-492, 2013b.

Venn, C.: Neoliberal political economy, biopolitics and colonialism: a transcolonial genealogy of inequality, Theor. Cult. Soc., 26, 206-233, 2009.

Vergara, C. J.: The New American Ghetto, Rutgers University Press, New Brunswick, NJ, 1995.

Wacquant, L.: The new "peculiar institution": on the prison as surrogate ghetto, Theor. Criminol., 4, 377-389, 2000.

Wacquant, L.: The advent of the penal state is not a destiny, Social Justice, 28, 81-87, 2001a.

Wacquant, L.: Deadly symbiosis: when ghetto and prison meet and mesh, in: Mass Imprisonment in The United States, edited by: Garland, D., Sage, London 82-120, 2001b.

Wacquant, L.: The body, the ghetto and the penal state, Qual. Sociol., 32, 101-129, 2009. 